\title{
PENYELENGgARAAN PEMBELAJARAN IPA BERBASIS PENDEKATAN STEM DALAM MENYONGSONG ERA REVOLUSI INDUSTRI 4.0
}

\section{Anggit Grahito Wicaksono}

\author{
Universitas Slamet Riyadi \\ *Corresponding Author: garahito@gmail.com
}

DOI: $10.24929 /$ lensa.v10i1.98

Received: 4 mei 2020

Revised: 23 Mei 2020

Accepted: 25 Mei 2020

\begin{abstract}
ABSTRAK
Pendidikan berbasis revolusi industri 4.0 memerlukan alternatif solusi yang membuat lembaga pendidikan harus selalu memadukan metode inovatif untuk meningkatkan pengajaran dan pembelajaran. Tujuan dari penelitian ini adalah untuk menganalisis aspek-aspek penunjang pembelajaran IPA serta cara mengimplementasikannya dalam menyongsong era revolusi industri 4.0. Metode Penelitian ini mengunakan metode library research. Hasil penelitian ini adalah (1) aspek-aspek penunjang dalam pembelajaran IPA yang memenuhi tuntutan revolusi industri 4.0 adalah menggunakan model pembelajaran inovatif berbasis masalah/proyek, menggunakan pendekatan yang melibatkan unsur sains, teknologi, dan masyarakat, serta dapat meningkatkan keterampilan abad 21 antara lain berpikir kritis, pemecahan masalah, dan kreativitas; dan (2) Implementasi pembelajaran IPA berbasis project based learning yang dikombinasikan dengan pendekatan STEM adalah contoh implementasi teknologi ramah lingkungan yang dapat meningkatkan kreativitas peserta didik dalam mengelola limbah sebagai sumber energi baru terbarukan.
\end{abstract}

Kata Kunci: Revolusi Industri 4.0, Pembelajaran IPA, Pembelajaran Berbasis STEM

\begin{abstract}
Education based on the industrial revolution 4.0 requires alternative solutions that make educational institutions must always integrate innovative methods to improve learning process. The purpose of this research is to analyze the aspects of supporting science learning and how to implement it in welcoming the era of the industrial revolution 4.0. This research method uses the library research method. The results of this study are (1) supporting aspects in learning science that meet the demands of the industrial revolution 4.0 is to use a problem/ project-based innovative learning model, using approaches that involve elements of science, technology, and society, and can improve $21^{\text {st }}$ century skills, among others critical thinking, creativity, and problem solving; and (2) The implementation of science based project based learning combined with the STEM approach is an example of the implementation of environmentally friendly technology that can enhance the creativity of students in managing waste as a new renewable energy source.
\end{abstract}

Keywords: Industrial Revolution 4.0, Natural Science Learning, STEM Based Learning

\section{PENDAHULUAN}

Industrial Revolution adalah sejarah terpenting dalam perkembangan kehidupan manusia dalam beberapa abad terakhir ini guna usaha pembangunan kehidupan berkelanjutan (Stearns, 2013). Para pengamat industri memiliki konsep perkembangan industri di seluruh dunia telah mencapai pda gelombang industrial revolution 4.0 atau Industri 4.0, ketika aktivitas industri telah sampai pada abad ke-21 yang mengalami revolusi digital, digunakan sebagai hasil pengembangan berkelanjutan dari revolusi industri yang telah ada. Industrial revolution 1.0 mulai menerapkan tenaga uap dalam proses produksi karena telah ditemukan mesin uap, industrial revolution 2.0 mulai menerapkan energi listrik dalam mengkreasikan produksi dalam skala besar, serta 
Industrial revolution 3.0 mulai dikembangkan teknologi komputerisasi informasi guna mengotomasi produksi (Hussin, 2018).

Industrial Revolution 4.0 diawali pada tahun 2018 dengan digunakan sistem cyber - physical. Dewasa ini kegiatan industri mulai memasuki dunia virtual digital yang menghubungkan antara manusia, mesin, dan data yang telah tersebar. Istilah ini dipahami sebagai Internet of Things (IOT). Pemerintah Indonesia telah menyiapkan antisipasi terhadap revolusi industri dengan menyusun roadmap mencakup sepuluh bidang kegiatan, tiga dari itu adalah SDM, teknologi, dan inovasi (Sunarno, 2018). Teknologi yang mengikuti perkembangan di era industrial revolution 4.0 ini memunculkan tantangan dan peluang baru dalam berbagai kegiatan manusia. Revolusi industri 4.0 memiliki kemungkinan untuk terjadinya peningkatan produktivitas, kualitas, dan efisiensi dalam proses produksi sehingga produk dapat berdaya saing global. Revolusi industri 4.0 adalah juga memungkinkan adanya kualitas hidup yang meningkat, transportasi dan komunikasi yang mudah, serta terwujudnya sistem keamanan kerja. Walaupun demikian, berbagai macam tantangan baru muncul pula sebagai konsekuensi sosial dari revolusi industri 4.0 seperti informasi yang tidak terkendali (information overload), banyaknya pengangguran karena ketidakmampuan kompetensi dan keterampilan, kesenjangan sosial perekonomian karena perkembangan teknologi membutuhkan dana yang cukup besar, serta adanya eksploitasi sumber daya alam yang berakibat pada kerusakan lingkungan (Isriwal, et.al., 2019).

Kondisi yang penuh dengan persaingan terjadi pada era revolusi industri 4.0. Menteri Ketenagakerjaan mengatakan bahwa daya saing tenaga kerja Indonesia harus diperkuat, dan tantangannya adalah dengan meningkatkan kompetensi dan keterampilan tenaga kerja dalam bidang sains, teknologi, teknik, dan matematika (Kompas, 2 Juli 2018). Di era industrial revolution 4.0, paradigma pendidikan yang menjadi kerangka acuan pendidikan saat ini tidak sesuai lagi untuk mengembangkan kualitas kemampuan dan keterampilan peserta didik. Oleh karena itu paradigma proses pendidikan niscaya akan mengalami perubahan yang cukup mendasar mengikuti tuntutan era industrial revolution 4.0. Konsekuensinya, industrial revolution 4.0 akan menginduksi revolusi dalam bidang pendidikan menjadi Pendidikan 4.0 (Isriwal, et. al., 2019). Pendidikan 4.0 merupakan metode yang dilakukan untuk melengkapi peristiwa integrasi digital dalam kehidupan nyata sehingga membuat manusia dan mesin melakukan interaksi untuk memecahkan masalah dan penemuan inovasi baru. Pendidikan 4.0 menyebabkan kemudahan dalam akses informasi serta proses pembelajaran menjadi sangat dinamis dan berkembang. Pendidikan 4.0 di masa yang akan datang dapat mengubah penggunaan informasi secara mudah dan cepat. Pendidikan berbasis revolusi industri 4.0 memerlukan alternatif solusi yang membuat lembaga pendidikan harus selalu memadukan metode pembelajaran aktif dan inovatif untuk meningkatkan proses pengajaran dan pembelajaran (Halili, 2019). Penelitian ini memiliki tujuan untuk menganalisis aspek-aspek penunjang pembelajaran IPA serta cara mengimplementasikannya dalam menyongsong era revolusi industri 4.0.

\section{METODE}

Penelitian ini menggunakan metode penelitian kepustakaan atau library research. Library research merupakan jenis penelitian yang dilakukan dengan menggunakan kepustakaan (literatur), dapat berupa buku referensi, laporan hasil penelitian oleh peneliti sebelumnya, maupun artikel ilmiah (Blaxter, 2010). Sumber data dibagi menjadi utama dan tambahan yang berasal dari artikel ilmiah dalam jurnal, laporan penelitian, dan buku referensi yang berkaitan dengan revolusi industri 4.0, karakteristik IPA, pembelajaran IPA, dan pembelajaran berbasis STEM. Teknil pengumpulan data adalah dokumentasi. Teknik analisis dalam penelitian ini mengacu pada teknik analisis deskriptif kualitatif. 


\section{HASIL DAN PEMBAHASAN}

\section{Sejarah Revolusi Industri 4.0}

Industrial revolution generasi pertama terjadi di Britania Raya pada akhir abad ke17 yang terjadi secara spontan tanpa adanya dorongan dari pemerintah dan merupakan generasi yang paling besar perubahannya dalam rangkaian generasi industrial revolution; dari konvensional menjadi berbasis teknologi (Savić, 2018). Sebelumnya di tahun 1760 sistem industri masih berbentuk industri rumah tangga dengan ciri khusus yaitu menggabungkan pertanian dan kegiatan industri dengan memperkerjakan dan melatih satu atau beberapa orang pekerja. Lahirnya penemuan mesin uap dan alat tenun listrik menjadi titik awal industri 1.0 yang merupakan zaman mesin industri pertama (Hartwell, 2017; Peters, 2017).

Industrial revolution 2.0 merupakan hasil upgrade dari industrial revolution 1.0 dimana sistem produksi pabrik telah menerapkan elektromagnetik dan memproduksi secara massal menggunakan sistem jalur perakitan (Zhou, Zhou, \& Liu, 2015). Industrial revolution 2.0 dirangsang oleh dua teori yaitu teori Maxwell dan Faraday yang menggabungkan kekuatan magnetik dan listrik. Kedua teori ini melahirkan motor listrik dan pembangkit listrik sehingga memainkan peran penting dalam jalur perakitan skala besar (Ravasoo, 2014).

Meskipun terdapat perbedaan yang signifikan antara karakteristik industri 1.0 dan industri 2.0, terdapat kesamaan antara kedua era revolusi industri ini yaitu penemuan teknologi baru yang mengubah tata cara sistem produksi di banyak pabrik. Demikian di era industri 3.0 dimana internet merupakan inovasi yang dikembangkan dengan kemajua teknologi yang memudahkan perusahaan untuk saling berkomunikasi melalu perangkat keras, jaringan perangkat lunak komputer, dan sistem telekomunikasi (Chung \& Kim, 2016)

Industrial revolution 4.0, yang sedang berlangsung saat ini, mengacu pada kemajuan teknologi modern di mana internet dan teknologi pendukung (seperti embbeded system/ sistem tertanam) berperan sebagai pusat pengoperasian integrasi sistem produksi. Konsep-konsep seperti Internet of Things (IoT), internet industri, komputasi awan (Cloud-based Manufactoring), dan Smart Manufacturing merupakan aspek penting dari konsep visioner revolusi industri keempat (Schumacher, Erol, \& Sihn, 2016). Gambar 1 mengilustrasikan perkembangan keempat generasi revolusi industri.

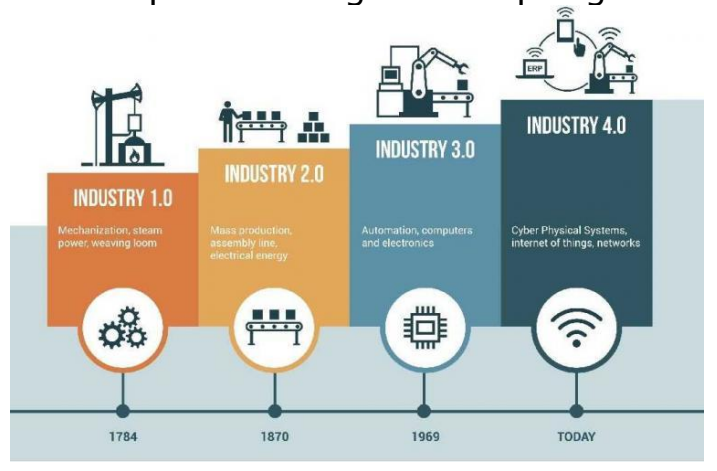

Gambar 1. Perkembangan Revolusi Industri di Dunia

(Sumber: http://kemenperin.go.id)

Terminologi industri 4.0 pertama kali dipublikasikan pada 2011 pada pameran di Hannover Jerman (Chung \& Kim, 2016). Bahkan gagasan industri 5.0 sudah mulai muncul di beberapa publikasi yang menekankan pada implikasi material-material biologis sebagai sumber daya berkelanjutan (Sachsenmeier, 2016). Konsep revolusi industri 4.0 berlandaskan teknologi yang rumit, seperti cyber-physical systems, internet untuk segala (IoT), komputasi awan, data besar, dan teknologi analisis canggih (Zhou dkk., 2015).

Aspek cyber-physical systems (CPS) merupakan bagian mendasar dari internet untuk segala. Sistem tersebut menghasilkan inovasi teknologi yang mampu melakukan berbagai fungsi kerja sehingga mampu membuat antara virtuil dan riil menjadi tidak ada batasnya (Ungurean, Gaitan, \& Gaitan, 2014). Teknologi inovatif yang mengintegrasikan 
aspek fisis dan digital guna menghasilkan produk terbaru disebut internet untuk segala (Internet of Things) (Wortmann \& Flüchter, 2015). Terminologi "Things" di Internet of Things mengacu pada dua aspek yaitu lingkungan dan fisis, di mana setiap things diintegrasikan dengan alat pendeteksi frekuensi gelombang radio untuk menghubungkan satu dengan yang lain (Ungurean dkk., 2014; Zhou dkk., 2015).

Adanya kemajuan teknologi di era revolusi industri saat ini tidak dipungkiri juga membawa tantangan sebagai konsekuensi dari industri 4.0 terutama untuk para tenaga kerja diantaranya: kompleksitas sistem pada perangkat yang digunakan; sistem berperan sebagai intelligent assistance; peningkatan kebutuhan tenaga kerja terampil; dampak pada organisasi kerja dan keseimbangan kehidupan kerja; dan cybersecurity (Ras, Wild, Stahl, \& Baudet, 2017; Arnold, 2016). Kompetensi inti yang dibutuhkan untuk menghadapi tantangan dari industri 4.0 (Hecklau, Galeitzke, Flachs, \& Kohl, 2016) ditunjukkan pada Tabel 1.

Tabel 1. Kategori Kompetensi Revolusi Industri 4.0

\begin{tabular}{ll}
\hline \multicolumn{1}{c}{ Kategori } & \multicolumn{1}{c}{ Kompetensi yang Dibutuhkan } \\
\hline Kompetensi Teknikal & Pengetahuan baru \\
& Kemampuan teknik \\
& Kemampuan pemahaman cepat \\
& Kemampuan memanfaatkan media \\
& Kemampuan pemrograman dan \\
& pengkodean \\
& Memiliki pemahaman IT Security System \\
\hline Kompetensi Metodologis & Kreativitas \\
& Berjiwa wirausaha \\
& Problem solving \\
& Conflict solving \\
& Kemampuan membuat keputusan \\
& Kemampuan menganalisis \\
& Keterampilan riset \\
& Berorientasi efisien \\
\hline Kompetensi Sosial & Kemampuan adaptasi berbagai budaya \\
& Kemampuan menggunakan bahasa \\
Kemampuan networking \\
Kemampuan bekerja sama dalam tim \\
Kemampuan mentransfer pengetahuan \\
Kemampuan memimpin \\
\hline Keksibilitas \\
Kemampuan bertoleransi/adaptasi \\
Motivasi untuk belajar \\
Mampu bekerja di bawah tekanan \\
Memiliki inisiatif \\
Mudah menyesuaikan dengan kemajuan \\
teknologi \\
\hline
\end{tabular}

\section{Karakteristik IPA dan Pembelajarannya}

Jasin (2012: 58) mengemukakan bahwa Sains (IPA) adalah jenis pengetahuan khusus, yang menghubungkan satu cara dengan cara lain dengan melakukan pengamatan, eksperimen, kesimpulan, dan persiapan teoretis. Lebih lanjut Sulistyorini, Tjandrakirana \& Soetjipto (2016) memiliki pendapat yang hampir sama, bahwa IPA adalah cara untuk mengeksplorasi secara sistematis alam sekitar sehingga tidak hanya menguasai akumulasi sistematis, menguasai kumpulan pengetahuan tetapi juga proses penemuan. Sedangkan menurut Iskandar (2016) lebih sederhana, bahwa IPA adalah studi tentang peristiwa yang terjadi di alam. Dua hal yang saling terkait yang tidak dapat dipisahkan dari IPA, yaitu IPA dalam bentuk pengetahuan konseptual sebagai suatu produk, dan IPA sebagai suatu proses, yaitu metode ilmiah (Maghfirah \& Herowati, 
2017). Sedangkan Hakikat IPA sendiri adalah proses ilmiah, produk, dan sikap ilmiah (Wicaksono, 2017).

Menurut Bybee, Carlson-Powell, \& Trowbridge (2014: 65), sains disini diartikan sebagai bangunan ilmu pengetahuan dan proses. Sedangkan Sund \& Carin (2010: 2) menerangkan dengan lebih lengkap bahwa "Science has three major elements: attitudes, processes or methods, and products. Attitudes are certain beliefs, value, opinions, for example, suspending judgment until enough data has been collected relative $o$ the problem. Constantly endeavouring to be objectif. Process or methods are certain ways of investigating problem, for example, making hypotheses, designing and carryng out experiments, evaluating data and measuring. Products are facts, principles, laws, theories, for example, the scientific principle: metals when heated expands." Pernyataan tersebut secara garis besar dapat diartikan bahwa pada hakikatnya IPA meliputi proses atau metode ilmiah adalah cara yang digunakan untuk menyelidiki masalah, produk ilmiah dapat berupa fakta, prinsip, hukum, dan teori, dan sikap ilmiah merujuk pada nilai tertentu yang mengiringi proses ilmiah.

Koballa dan Chiappetta (2010: 105) mengatakan bahwa IPA adalah cara mengembangkan kemampuan berpikir, cara mengivestigasi suatu masalah, kumpulankumpulan dari segala pengetahuan, dan kaitannya dengan teknologi dan kemasyarakatan. Hal ini menunjukkan bahwa IPA sebagai produk ilmiah berisi kumpulan pengetahuan meliputi prinsip, konsep, teori, dan hukum, IPA sebagai proses ilmiah mengacu pada cara menginvestigasi suatu masalah menggunakan keterampilan proses sains atau biasa disebut metode ilmiah, IPA sebagai sikap ilmiah mengacu pada cara mengembangkan kemampuan berpikir seperti ketelitian, curiosity, kejujuran, pemikiran kritis, dan sebagainya, dan IPA sebagai aplikasi adalah penggunaan konsep-konsep abstrak yang dapat dimanifestasikan dalam bentuk-bentuk spesifik maupun teknologi sebagai upaya untuk menerapkan konsep-konsep ilmiah yang akan berguna dalam caracara praktis untuk menyelesaikan berbagai masalah sains di masyarakat. IPA adalah mata pelajaran yang sulit untuk diselesaikan oleh peserta didik, sehingga diperlukan pembelajaran yang dapat mengkorelasikan antara konsep sains dengan konteksnya dalam kehidupan sehari-hari, sehingga proses pembelajaran menjadi lebih bermakna dan berdaya guna bagi peserta didik (Indriati \& Riskiyah, 2017).

Pembelajaran IPA adalah proses yang dapat membantu peserta didik belajar lebih bermakna melalui keterampilan proses sehingga mereka dapat menguasai pengetahuan ilmiah dan hukum alam serta menerapkannya dalam konteks kehidupan nyata. Pembelajaran IPA seharusnya mampu menghubungkan situasi secara langsung dan kondisi nyata, karena IPA memiliki focus mempelajari segala sesuatu yang ada di alam (Gita, Annisa, \& Nanna, 2018). Kurikulum 2013 menyatakan bahwa pembelajaran IPA bersifat kontekstual yang mengkaitkan konsep IPA dengan peristiwa dalam konteks kehidupan nyata peserta didik. Strategi pembelajaran IPA di kelas harus mampu berkontribusi dalam membentuk kreativitas peserta didik sebagai generasi yang dapat diandalkan di masa yang akan datang. Peserta didik diharapkan mampu menjadi generasi yang unggul, inovatif, produktif, dan kreatif di era industrial revolution 4.0.

\section{Pembelajaran Berbasis STEM (Science, Technology, Engineering, and Mathematics)}

Konsep pendidikan STEM di dunia modern merupakan integrasi bermakna dari beragam cabang ilmu yang digunakan untuk menyelesaikan permasalahan di dunia nyata (Beach, Henderson, \& Finkelstein, 2012; DeCoito, et. al., 2013). Beberapa aspek yang dapat dikembangkan melalui integrasi pembelajaran sains dan terapannya merupakan kapabilitas lulusan pendidikan STEM yang meliputi: skills (riset, belajar dan menyelidiki; problem solving, technical skills dan observasi, melakukan eksperimen, dan menyajikan presentasi); ways of thinking (analitis, logis, berfikir kritis, sistematis, terstruktur; kemampuan bertanya, mengevaluasi, mandiri; memberikan alasan, objectif, berbasis fakta, rasional; open-minded; inovatif, kreatif, dan berfikir lateral/berbagai sudut pandang) dan knowledge (metode saintifik, sains sebagai proses; pembelajaran terintegrasi STEM; pengetahuan dan kosakata berbasis pengetahuan STEM) (West, 2012). Aspek kemampuan tersebut linear terhadap kualifikasi kebutuhan tenaga kerja di era industri 4.0 sesuai dengan Tabel 1 . Oleh karena itu, sangat penting untuk 
mengembangkan pembelajaran tidak hanya terorientasi hanya untuk satu cabang ilmu tertentu (disciplinary), melainkan bersifat transdisiplin sehingga pengetahuan dan keahlian yang diperoleh dari berbagai sumber ilmu mampu diaplikasikan pada real-world problems dan meningkatkan pengalaman belajar peserta didik (English, 2016).

Pendekatan STEM menekankan pada aspek proses pembelajaran. Strategi pendekatannya meliputi: (1) pengajuan pertanyaan dan pendefinisian masalah; (2) pengembangan model dan perencanaan investigasi; (3) analisis, penafsiran data memanfaatkan matematika (statistic), teknologi informasi dan komputerisasi; (4) membangun klarifikasi, solusi desain, dan argumen berbasis bukti; (5) simpulan, evaluasi dan komunikasi. Tujuan dari pendekatan STEM untuk menerapkan konsep. Peserta didik dapat mengembangkan kompetensi yang harus diterapkan dalam berbagai situasi dan permasalahan yang muncul dalam kehidupan nyata. Tujuan pembelajaran berbasis STEM juga untuk membuat peserta didik memiliki keseimbangan antara hard dan soft skill, dan memiliki kreativitas (Sunarno, 2018).

Adapun manfaat lain yang secara spesifik ditemukan melalui pendidikan STEM terintegrasi adalah mengembangkan peserta didik menjadi pemecah masalah yang lebih baik, inovator, penemu, mandiri, logis, serta melek teknologi (ALTAN \& Ercan, 2016). Tabel 2 meringkas beberapa fokus yang perlu diperhatikan dalam mengintegrasi pembelajaran IPA melalui pembelajaran STEM terintegrasi (Stohlmann, Moore, \& Roehrig, 2012).

Tabel 2. Model S.T.E.M dalam pembelajaran STEM Terintegrasi

\section{Support (Pendukung)}

- Adanya kerjasama dengan universitas atau sekolah lain

- Menghadirkan profesional bidang pengembangan

- Adanya kolaborasi guru bidang studi

- Pelatihan dan pengembangan kurikulum

\begin{tabular}{|c|c|}
\hline \multicolumn{2}{|c|}{ Teaching (Sistem Pembelajaran) } \\
\hline Lesson Planing (Rencana Pembelajaran) & Classroom Practices (Kegiatan Kelas) \\
\hline 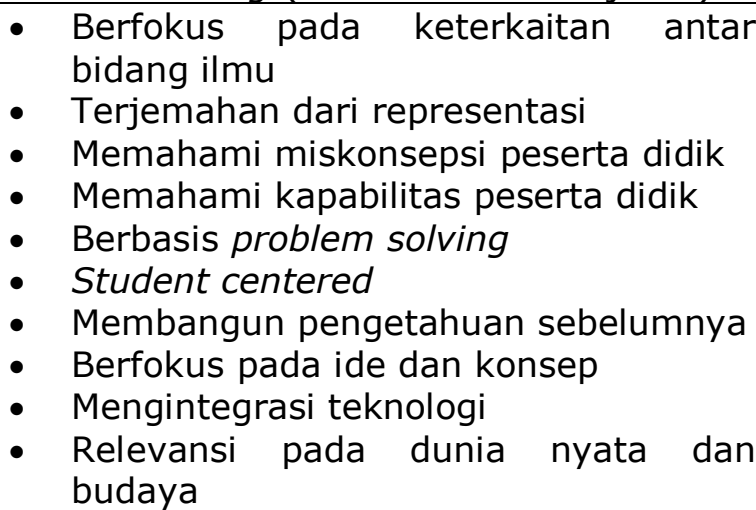 & $\begin{array}{l}\text { - } \text { Mengajukan pertanyaan dan membuat } \\
\text { - } \quad \text { Pemikotesis } \\
\text { - } \text { Kemamperan berbasis ilmiah } \\
\text { - } \quad \text { Fokus pada pola pemahaman } \\
\text { - } \quad \text { Menggunakan penilaian (assessment) } \\
\text { sebagai bagian dari instruksi } \\
\text { pembelajaran } \\
\text { - Pembelajaran kooperatif } \\
\text { - } \quad \text { Media pembelajaran yang efektif } \\
\text { - Inkuiri }\end{array}$ \\
\hline
\end{tabular}

\section{Efficacy (Tingkat Keberhasilan)}

- Content knowledge dan pedagogical knowledge berkontribusi untuk membangun self-efficacy yang positif

- Komitmen yang tinggi

- Perencanaan dan pengorganisasian sangat penting

- Sumber-sumber teknologi

- Wawasan teknologi

- Materials kits untuk aktivitas belajar (contoh pada kegiatan laboratorium)

- Ruang penyimpanan kit pembelajaran

- Meja-meja untuk kegiatan belajar berkelompok

\section{Implementasi Pembelajaran IPA Berbasis STEM di Era Revolusi Industri 4.0}

Implementasi pembelajaran IPA berbasis pendekatan STEM di era industrial revolution 4.0 seperti yang telah dicontohkan oleh Widha Sunarno (2018) dengan mengintegrasikan Project Based Learning, Pendekatan STEM Terintegrasi, dan Kreativitas Peserta Didik. Tabel 3. menunjukan pola keterkaitan antara PjBL, Pendekatan 
STEM, dan Kreativitas dalam pembelajaran IPA materi Biogas sebagai Sumber Energi Terbarukan.

Tabel 3. Pola Keterkaitan PjBL, Pendekatan STEM, dan Kreativitas

\begin{tabular}{|c|c|c|c|}
\hline $\begin{array}{c}\text { Project Based } \\
\text { Learning }\end{array}$ & $\begin{array}{c}\text { Pendekatan } \\
\text { STEM }\end{array}$ & $\begin{array}{c}\text { Kegiatan Peserta } \\
\text { Didik }\end{array}$ & Kreativitas \\
\hline $\begin{array}{l}\text { Penentuan } \\
\text { manfaat limbah } \\
\text { produksi tahu }\end{array}$ & $\begin{array}{l}\text { - Pengajuan } \\
\text { pertanyaan } \\
\text { - Pendefinisian } \\
\text { masalah }\end{array}$ & $\begin{array}{l}\text { Penentuan masalah } \\
\text { pencemaran akibat air } \\
\text { limbah produksi tahu }\end{array}$ & $\begin{array}{l}\text { Rasa ingin tahu, } \\
\text { mengemukakan } \\
\text { ide }\end{array}$ \\
\hline $\begin{array}{l}\text { Perancangan } \\
\text { penyusunan } \\
\text { langkah-langkah } \\
\text { penyusunan } \\
\text { proyek }\end{array}$ & $\begin{array}{l}\text { - Pengembangan } \\
\text { model } \\
\text { - Perencanaan } \\
\text { investigasi }\end{array}$ & 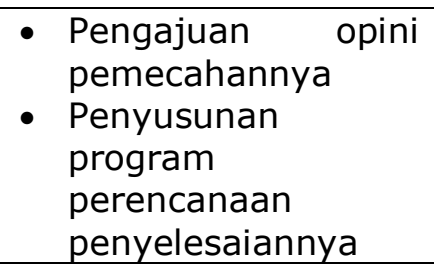 & $\begin{array}{l}\text { Memberikan } \\
\text { pertanyaan yang } \\
\text { relevan }\end{array}$ \\
\hline $\begin{array}{l}\text { Penentuan tahap } \\
\text { penyelesaian } \\
\text { proyek }\end{array}$ & 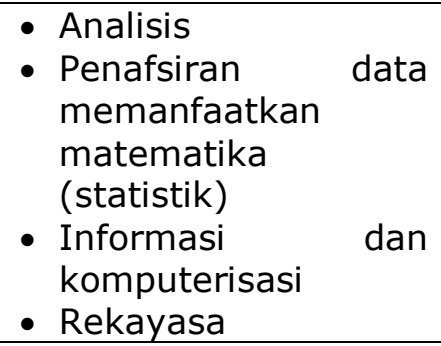 & $\begin{array}{l}\text { - Pengumpulan } \\
\text { informasi } \\
\text { - Penyusunan alat } \\
\text { dan bahan menjadi } \\
\text { bentuk instalasi }\end{array}$ & $\begin{array}{l}\text { Mengusulkan } \\
\text { gagasan } \\
\text { terhadap suatu } \\
\text { masalah }\end{array}$ \\
\hline $\begin{array}{l}\text { Penyelesaian } \\
\text { proyek }\end{array}$ & $\begin{array}{ll}\text { - } & \text { Membangun } \\
\text { klarifikasi } \\
\text { - Solusi desain } \\
\text { - Argumen berbasis } \\
\text { bukti }\end{array}$ & $\begin{array}{lr}\text { Menyelesaikan } & \text { proyek } \\
\text { sesuai } & \text { dengan } \\
\text { perencanaan } & \text { bentuk } \\
\text { instalasi } & \end{array}$ & $\begin{array}{l}\text { Memandang } \\
\text { masalah dari } \\
\text { berbagai } \\
\text { perspektif }\end{array}$ \\
\hline $\begin{array}{l}\text { Penyusunan } \\
\text { laporan, } \\
\text { Presentasi, dan } \\
\text { Publikasi }\end{array}$ & $\begin{array}{l}\text { - Simpulan } \\
\text { - Evaluasi } \\
\text { - Komunikasi }\end{array}$ & 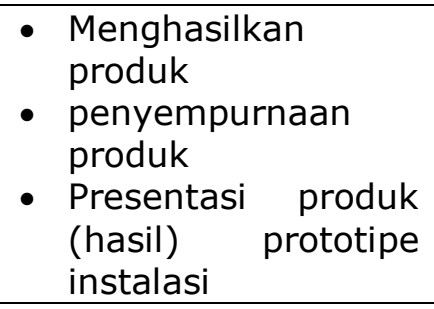 & $\begin{array}{l}\text { Orisinalitas pada } \\
\text { pemecahan } \\
\text { masalah }\end{array}$ \\
\hline
\end{tabular}

Sumber: Sunarno (2018)

\section{SIMPULAN}

Revolusi Industri 4.0 menghadirkan tantangan nyata, terutama bagi para pendidik, untuk menciptakan generasi yang berdaya saing global. Dengan kemajuan teknologi yang dihasilkan dari dampak revolusi industri 4.0, pendidik dan pengamat pendidikan dapat menggunakannya untuk mengembangkan dan mengintegrasikan dalam proses pembelajaran, sehingga tidak hanya mengembangkan kemampuan kognitif peserta didik.

Sebagai hasil dari pembelajaran saat ini, individu yang berpendidikan akan memutuskan untuk menyediakan sumber daya manusia sebagai generasi kreatif dan inovatif guna mendukung kemandirian nasional di masa depan. Aspek-aspek penunjang dalam pembelajaran IPA yang memenuhi tuntutan revolusi industri 4.0 adalah menggunakan model pembelajaran inovatif berbasis masalah/proyek, menggunakan pendekatan yang melibatkan unsur sains, teknologi, dan masyarakat, serta dapat meningkatkan keterampilan abad 21 antara lain berpikir kritis, pemecahan masalah, dan kreativitas. Implementasi dalam pembelajaran peserta didik harus dilakukan secara aktif agar dapat mengoptimalkan potensi lokal menjadi produk yang bermanfaat bagi masyarakat. 
Implementasi pembelajaran IPA berbasis project based learning yang dikombinasikan dengan pendekatan STEM adalah contoh implementasi teknologi ramah lingkungan yang dapat meningkatkan kreativitas peserta didik dalam mengelola limbah sebagai sumber energi baru terbarukan. Oleh karena itu, diharapkan kegiatan yang dilakukan oleh peserta didik akan membantu membentuk karakter kreatif dan inovatif serta memainkan peran penting dalam kelangsungan hidup negara dan kehidupan negara dalam menyongsong era revolusi industri 4.0 dan generasi emas 2045 .

\section{SARAN}

Saran dan rekomendasi bagi pendidik maupun peserta didik adalah pendidik hendaknya mampu mengimplementasikan pembelajaran IPA dengan berbasis pendekatan STEM dalam berbagai materi terkait khususnya IPA Modern/Kontemporer untuk menyongsong Era Revolusi Industri 4.0 serta peserta didik hendaknya memaksimalkan potensi dirinya sehingga dapat berkontribusi dalam membentuk karakter kreatif dan inovatif serta memainkan peran penting dalam kelangsungan hidup negara dan kehidupan dalam menyongsong era revolusi industri 4.0 dan generasi emas 2045.

\section{REFERENSI}

ALTAN, E. B., \& Ercan, S. (2016). STEM education program for science teachers: perceptions and competencies. Journal of Turkish Science Education, 13(special), 103-117.

Arnold, G. (2016). Viewpoint: Intelligent Systems: A New Industrial Revolution. IEEE Electrification Magazine, 4(1), 63-64.

Beach, A. L., Henderson, C., \& Finkelstein, N. (2012). Facilitating change in undergraduate STEM education. Change: The Magazine of Higher Learning, 44(6), 52-59.

Blaxter, L. (2010). How to research. McGraw-Hill Education (UK).

Bybee, R. W., Carlson-Powell, J., \& Trowbridge, L. W. (2014). Teaching secondary school science: Strategies for developing scientific literacy. Pearson Education Limited.

Chung, M., \& Kim, J. (2016). The internet information and technology research directions based on the fourth industrial revolution. KSII Transactions on Internet and Information Systems, 10(3), 1311-1320.

DeCoito, I., Steele, A., Goodnough, K., Bagshaw, E., Sanders, M., Statistics Canada, ... \& Statistiques Canada.(2013). National Household Survey (2011)-Education in Canada: Attainment, field of study and location of study. Ottawa, ON, Canada: Ministère de l'innovation, des sciences et du développement économique. (2016). STEM, STEM education, STEMmania.

English, L. D. (2016). STEM education K-12: perspectives on integration. International Journal of STEM Education, 3(1), 1-8.

Gita, S. D., Annisa, M., \& Nanna, W. I. (2018). Pengembangan Modul IPA Materi Hubungan Makhluk Hidup dan Lingkungannya Berbasis Pendekatan Kontekstual. LENSA (Lentera Sains): Jurnal Pendidikan IPA. 8 (1).28-37.

Halili, S. H. (2019). Technological Advancements In Education 4.0, The Online Journal of Distance Education and e-Learning, 7(1), 63-69.

Hartwell, R. M. (2017). The Causes of The Industrial Revolution in England. Routledge.

Hecklau, F., Galeitzke, M., Flachs, S., \& Kohl, H. (2016). Holistic Approach for Human Resource Management in Industry 4.0. Procedia CIRP, 54, 1-6.

Hussin, A. A. (2018). Education 4.0 made simple: ideas for teaching. International Journal of Education \& Literacy Studies, 6(3), 92-98.

Indriati, I., \& Riskiyah, R. (2017). Pembelajaran Kontekstual Menggunakan Media Konkrit Untuk Meningkatkan Hasil Belajar IPA Siswa Kelas IX Pada Pokok Bahasan Wujud Benda Di SMP Negeri 1 Dasuk. LENSA (Lentera Sains): Jurnal Pendidikan IPA, 7(2), 89-95. 
Iskandar, S. M. (2016). Pendekatan keterampilan metakognitif dalam pembelajaran sains di kelas. Erudio Journal of Educational Innovation, 2(2), 13-20.

Isriwal, P. A., Firman, F., \& Rusdinal, R. (2019). Kompetensi Guru: Dalam Mewujudkan Generasi Berkarakter dan Terampil di Era 4.0. Jurnal Pendidikan Tambusai, 3(3), 1627-1632.

Jasin, M. (2012). Ilmu Alamiah Dasar. Jakarta: Rajawali Press

Koballa \& Chiapetta. (2010). Science Instruction in the Middle and Secondary Schools. USA: Pearson.

Kompas. (2018). Perkuat Daya Saing oleh Meteri Ketenagakerjaan Hanif Dhakiri. Diterbitkan tanggal 2 Juli 2018.

Maghfirah, F., \& Herowati, H. (2017). Pengembangan Media Komik Strip Sains "Pemanasan Global" Untuk Meningkatkan Motivasi Membaca Siswa Kelas Vii Smpn 2 Sumenep. LENSA (Lentera Sains): Jurnal Pendidikan IPA, 7(2), 76-84.

Peters, M. A. (2017). Technological unemployment: Educating for the fourth industrial revolution. Educational Philosophy and Theory, 49(1), 1-6.

Ras, E., Wild, F., Stahl, C., \& Baudet, A. (2017). Bridging the Skills Gap of Workers in Industry 4.0 by Human Performance Augmentation Tools, 428-432.

Ravasoo, A. (2014). Interaction of bursts in exponentially graded materials characterized by parametric plots. Wave Motion, 51(5), 758-767.

Sachsenmeier, P. (2016). Industry 5.0 - The Relevance and Implications of Bionics and Synthetic Biology. Engineering.

Savić, D. (2018). Rethinking the role of grey literature in the fourt industrial revolution. Grey Journal, 14 (Special Winter Issue), 7-14.

Schumacher, A., Erol, S., \& Sihn, W. (2016). A Maturity Model for Assessing Industry 4.0 Readiness and Maturity of Manufacturing Enterprises. Procedia CIRP, 52, 161166.

Stearns, P. N. (2013). The Industrial Revolution in World History (4th ed.). USA: Westview Press.

Stohlmann, M., Moore, T., \& Roehrig, G. (2012). Considerations for Teaching Integrated STEM Education. Journal of Pre-College Engineering Education Research, 2(1), 28-34.

Sulistyorini, A., Tjandrakirana, T., \& Soetjipto, S. (2017). Pengembangan Perangkat Pembelajaran IPA Model Guided Inquiry untuk Melatihkan Keterampilan Proses Sains dan Meningkatkan Hasil Belajar Siswa SMP. JPPS (Jurnal Penelitian Pendidikan Sains), 6(1), 1167-1174.

Sunarno, W. (2018). Pembelajaran IPA di Era Revolusi Industri 4.0. Makalah Utama dalam Seminar Nasional Pendidikan Fisika IV 2018 di Universitas PGRI Madiun Tanggal 25 Juli 2018.

Sund, R. B., \& Carin, A. A. (2010). Teaching science through discovery. Columbus: Charles E. Merill.

Ungurean, I., Gaitan, N. C., \& Gaitan, V. G. (2014). An IoT architecture for things from industrial environment. IEEE International Conference on Communications, (May).

West, M. (2012). Chief Scientist STEM Education And The Workplace, (4), 1-4.

Wicaksono, A. G. (2017). Penguatan pendidikan karakter Melalui pembelajaran ilmu alamiah dasar. Widya Wacana: Jurnal IImiah, 11(2).

Wortmann, F., \& Flüchter, K. (2015). Internet of Things: Technology and Value Added. Business and Information Systems Engineering, 57(3), 221-224.

Zhou, keliang, Zhou, L., \& Liu, T. (2015). Industry 4.0: Towards Future Industrial Opportunities and Challenges: FSKD 2015: 15-17 August, Zhangjiajie, China. 12th International Conference on Fuzzy Systems and Knowledge Discovery, 0-5. 